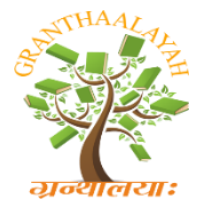

\author{
INTERNATIONAL JOURNAL OF RE
GRANTHAALAYAH \\ A knowledge Repository
}

Social

\title{
ANALYSIS OF SENIOR SECONDARY EXAMINATION QUESTIONS ACCORDING TO REVISED BLOOMS TAXONOMY COMPLEXITY
}

\author{
Prashant Thote *1, Gowri. S ${ }^{2}$ \\ ${ }^{* 1,2}$ Gyanodaya Vidya Mandir, India
}

\begin{abstract}
In this paper attempt is made to investigate summative examination questions of grade 11 according to cognitive complexity. Total 12 senior secondary schools grade 11 question papers of the academic year 2018-19 end exams are considered in the present study. Total 384 questions are asked. In the present study conducted - theory based content analysis and qualitative methodology is employed by using revised Bloom's taxonomy of cognitive objectives. Higher order thinking, middle order thinking and lower order thinking skills based questions are structured. The present research is guided by research question "What kind of cognitive skills and knowledge do grade 11 examination questions require?" Result of the study reveals that year end examinations are demanding. 52\% questions are from higher order cognitive skills. Revised Bloom's Taxonomy is used for designing the assessment tool. The two higher order thinking skills categories should be more evenly present in the exam.
\end{abstract}

Keywords: Critical Thinking; Instructional Evaluation; Chemistry; Examination; Cognitive Skills.

Cite This Article: Prashant Thote, and Gowri. S. (2020). "ANALYSIS OF SENIOR SECONDARY EXAMINATION QUESTIONS ACCORDING TO REVISED BLOOMS TAXONOMY COMPLEXITY.” International Journal of Research - Granthaalayah, 8(3), 119-127. https://doi.org/10.29121/granthaalayah.v8.i3.2020.136.

\section{Introduction}

High order thinking skills such as reasoning skills, logical thinking, and critical thinking are the basic skills required in our day to day life to survive in this competitive and complex world. The key elements of the educational scheme are to nurture students to furnish themselves to apply knowledge of science in many circumstances. The students' performance in science not only at national assessment but also at international assessment includes high order thinking skills and is becoming a guideline for education system and policy makers.

As a teacher, it is our responsibility to increase students high order thinking skills. Questions on high order thinking skills will play a significant role in daily class-room instructions. Teachers questioning in class-room on regular basis for centuries is used as an instrument to assess student's conceptual knowledge, to develop high order thinking skills and to nurture comprehension among 
students. The class room instructional questions catalyses students' cognitive process at different complexity and level.

In $21^{\text {st }}$ century there is a strong need to prepare young generations with middle order thinking skills as it is necessary for lifelong learning and to compete in a competitive artificial intelligence based job market. In modern education system, creative and critical thinking are essential elements. Hence as a teacher, we are urged to get best possible ways and provide an opportunity for student's trough thinking in classroom practice.

To cultivate high order thinking skills among students, teachers questioning is panacea. Students conceptual understanding, thinking, interest, positive attitude may be enhanced when teachers facilitate an interactive and interesting class-room questioning. Teachers questioning skills, application of frame works for amalgamation of high order thinking skills has been widely studied but types of question posed by teachers and the impact on students high order thinking skills in chemistry remain unexplored.

In school at senior secondary level the questioning skills of teachers' catalysed march towards high order thinking skills among students. The questioning session during class room instructions are important in making class room instructions effective and efficient. The type of question teachers raise may influence the kind of cognitive process like, the student may participate, involve, engage in the process of construction of knowledge. It is observed that students conceptual understanding, thinking may be nurtured with social context in class-room climate when interactive discourse through questioning is adopted by teachers. The teachers questioning skills during class-room instruction is significant element in students' performance.

Assessment is the key element in our education system. It is well known fact that students and teachers work towards success in examination. Student's performance in summative assessment is predictive, comparable and gives an overview of student's previous learning. At end of an instructional teaching summative assessment is implemented to grade and document the student's performance in preparation of some pre-determined instructional standards and other student's performance.

The present opinion founded on constructivism, assessment is supposed to tap high order thinking skills such as problem-solving skills, application of conceptual knowledge in new situation etc., among students. Summative assessment not only measures students' low order thinking skills like their ability to remember factual knowledge but also their capacity to solve routine algorithmic exercises. Mostly at grade 11 traditional low order thinking skills type examination is dominated in chemistry education.

The revised Bloom's Taxonomy constructed by Anderson and Krathwohl (2001) is termed in Table-1 (Taxonomy Table)

Two-dimensional scheme applicable for chemistry learning objectives and summative examinations questions in knowledge dimension and cognitive process. The verbs and noun aspects of examination question (analyzed data) are applied for the process of classification. The 
verb forms the basis for cognitive process dimension and noun provide basis for the knowledge dimension.

Table 1: The Blooms Taxonomy Table

\begin{tabular}{|l|l|l|l|l|l|l|l|}
\hline $\begin{array}{l}\text { Sl. } \\
\text { No }\end{array}$ & $\begin{array}{l}\text { Knowledge } \\
\text { Dimension }\end{array}$ & Remember & Understanding & Apply & Analyze & Evaluate & Create \\
\hline 1 & Factual & & & & & & \\
\hline 2 & Conceptual & & & & & & \\
\hline 3 & Procedural & & & & & & \\
\hline 4 & Meta -Cognitive & & & & & & \\
\hline
\end{tabular}

In Blooms taxonomy table the hierarchy in which cognitive complexity is arranged is from simple to complex from left to right. The knowledge dimensions are considered in line along the continuum from concrete (factual) to abstract (meta-cognitive). The revised Bloom's taxonomy allows overlapping six domains with one another and it is flexible but original Bloom's Taxonomy was rigid in this context.

\section{Example}

The few examination questions in chemistry are classified under 'Understanding' (e.g. questions in which students have to explain chemical phenomena) will be more cognitively complex than other questions classified under the category 'Apply' (e.g. socio-metric problems).

The Bloom's Taxonomy knowledge domains are further divided into major four types: factual knowledge, conceptual knowledge, procedural knowledge and meta-cognitive knowledge. The knowledge dimensions applied in context of chemistry examination are represented in Table- 2.

Table 2: Knowledge Dimension

\begin{tabular}{|c|c|c|c|}
\hline Sl. No & Type of Knowledge & Definition & Example \\
\hline 1 & Factual & $\begin{array}{l}\text { Elements, specific detail, } \\
\text { knowledge of terminology. }\end{array}$ & 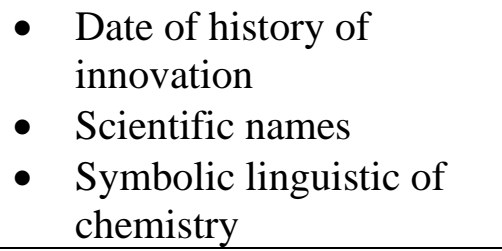 \\
\hline 2 & Conceptual & $\begin{array}{l}\text { Structure, models, theories, } \\
\text { principles, categories, } \\
\text { generalization, knowledge of } \\
\text { classification. }\end{array}$ & $\begin{array}{l}\text { - } \quad \text { Atomic theory. } \\
\text { - Le-Chatelier's principles. } \\
\text { - Periodic tables of } \\
\text { element. }\end{array}$ \\
\hline 3 & Procedural & $\begin{array}{l}\text { Algorithms, methods, } \\
\text { techniques, subject specific } \\
\text { skills, criteria for } \\
\text { determination, application of } \\
\text { appropriate procedure. }\end{array}$ & $\begin{array}{ll}\text { - } & \text { Chemistry invention } \\
\text { methods } \\
\text { - } \\
\text { - } \text { Investigation methods } \\
\text { - } \quad \text { Mathematical operations }\end{array}$ \\
\hline 4 & Meta-Cognitive & $\begin{array}{l}\text { Knowledge of own cognition } \\
\text { awareness }\end{array}$ & $\begin{array}{ll}\text { - } & \begin{array}{l}\text { Strengths and weakness } \\
\text { (students) }\end{array} \\
\text { - } & \text { Test-strategies } \\
\end{array}$ \\
\hline
\end{tabular}


The cognitive domains of Bloom's Taxonomy are categorized under six major divisions such as remember, understand, apply, analyse, evaluate and create. The cognitive process domain used in the context of chemistry examination questions are represented in Table-3.

Table 3: Cognitive Dimension

\begin{tabular}{|c|c|c|c|}
\hline & Category & Definition & Examples \\
\hline \multirow[b]{2}{*}{$\begin{array}{l}\text { Low order } \\
\text { thinking } \\
\text { skills }\end{array}$} & Remember & $\begin{array}{l}\text { Retrieve relevant knowledge } \\
\text { from long term memory } \\
\text { (recalling and recognition) }\end{array}$ & $\begin{array}{l}\text { - Recalling the dates of } \\
\text { historical chemical } \\
\text { innovations. } \\
\text { - Recognizing chemical } \\
\text { symbol of elements }\end{array}$ \\
\hline & Understand & $\begin{array}{l}\text { Build meaning from instructional } \\
\text { message, oral, written, graphic } \\
\text { communication, explaining, } \\
\text { inferring, summarizing, } \\
\text { classifying, exemplifying and } \\
\text { interpreting. }\end{array}$ & $\begin{array}{l}\text { Explanation of direction of } \\
\text { equilibrium } \\
\text { - Comparing and contrasting } \\
\text { elements of periodic table. } \\
\text { - Organic compound: } \\
\text { interring molecular structure } \\
\text { - Providing examples of } \\
\text { organic compounds } \\
\text { - Chemical concepts } \\
\text { paraphrasing } \\
\text { - An article summarizing }\end{array}$ \\
\hline \multirow[b]{2}{*}{$\begin{array}{l}\text { Middle } \\
\text { order } \\
\text { thinking } \\
\text { skills }\end{array}$} & Apply & $\begin{array}{l}\text { Application/classifying } \\
\text { procedure in given situation. }\end{array}$ & $\begin{array}{l}\text { - Application of ideas and } \\
\text { law in situation } \\
\text { - Distillation }\end{array}$ \\
\hline & Analyse & $\begin{array}{l}\text { Differentiation, attributing, } \\
\text { organizing, breaking material } \\
\text { into constituents and establishing } \\
\text { relationship between parts }\end{array}$ & $\begin{array}{l}\text { - Identifying attitude of } \\
\text { writers/authors in articles of } \\
\text { chemistry. } \\
\text { - Chemical report: Analysis } \\
\text { - Identify essential elements } \\
\text { of problems }\end{array}$ \\
\hline \multirow{2}{*}{$\begin{array}{l}\text { High } \\
\text { order } \\
\text { thinking } \\
\text { skills }\end{array}$} & Evaluate & $\begin{array}{l}\text { Checking, criticizing, and } \\
\text { making judgments on strands } \\
\text { and criteria. }\end{array}$ & $\begin{array}{l}\text { - Compare and contrast } \\
\text { different chemical methods. } \\
\text { - Analyzing reasonable test } \\
\text { solution. }\end{array}$ \\
\hline & Create & $\begin{array}{l}\text { Generation, producing, planning, } \\
\text { putting elements together to form } \\
\text { whole functionally coherent new } \\
\text { pattern of elemental recognition. }\end{array}$ & $\begin{array}{l}\text { - Writing essay on chemistry } \\
\text { - Fabricating hypothesis } \\
\text { - } \text { Planning chemical methods. }\end{array}$ \\
\hline
\end{tabular}

Recently more researches are conducted on knowledge skills and cognitive skills in chemical education (Aksda, 2009). L. Mathew (2010) studied secondary school social studies examination questions in terms of the level of thinking domain of Bloom's taxonomy. Her research results reveals that $94 \%$ social science question papers are on low order thinking skills and middle order thinking skills type and required application, comprehension and knowledge. Only 6\% questions 
are at high order thinking skills (analysis, synthesis and evaluation level). Her study shows that question type are reveled to low classes of school.

D.P.S. Rathore (2011) classified chemistry examination question paper according to Bloom's Taxonomy. Research result shows that majority of questions are based on low order cognitive skills. The comprehension level questions are significant. Application based questions are more. Analysis based questions are in very less quantity. The synthesis-based questions are very few and evaluation based questions are not included.

Prashant Thote and L. Mathew (2012) investigated students performance in chemistry at secondary school examination requires low order thinking skills and high order thinking skills at senior secondary school examination emphasis on low order thinking skills. A different pattern of students' performances is seen in high order thinking skills and low order thinking skills. Higher performance of the students does not assure a high performance on former. Most of the students do not perform well on the supposedly basic low order thinking skills questions, as compared to their performance in high order thinking skills questions. Result of the study reveals that insufficient pre-examination preparation.

Prashant Thote and L. Mathew (2014) conducted a study on grade 11 chemistry students where the top achieving students were given free choice questions between low order thinking skills and high order thinking skills type questions, students preferred low order thinking skills type questions. Results of the study reveals that high order thinking skills oriented questions instructions are not sufficient for changing attitude with respect to low order thinking skills and high order thinking skills.

\section{High Order Thinking Skills Questions}

They are qualitative, quantitative, structural, open ended questions, mostly not familiar with students who have solution/answer much more than simply knowledge, application of known algorithms and required the analysis, synthesis, problem solving capabilities, decision making, critical evaluative thinking and making connectivity. It involves application of knowledge /theory to unknown/unfamiliar situation with unusual dimension/elements.

\section{Low Order Thinking Skills Questions}

They include knowledge based questions that simply require recall of information, simple application of known theory, principles and knowledge familiar to known context and situation. Problems/numerical mostly based on conceptualized exercise answered by application of taught/known/recall algorithms and not essentially students who understood which are already known/familiar to the students through previous specific directions and long-term practice.

The summative assessment is dominant tool at senior secondary school for grade 11 students. Chemistry is elective subject at senior secondary school level. In grade 11 structure and question of test designed by concern teachers on the goals and content defined in senior secondary curriculum. The grade 11 examination is very significant to investigate a detailed answer for questions: what kind/type of cognitive and knowledge did the chemistry summative examination of private school measure. 


\section{Methods}

The theory-based analysis of content analysis along with quantitative approach method is employed in the present research. The summative examination questions are classified into two domains such as knowledge dimension and cognitive process. The revised Bloom's taxonomy was applied in the present research as it is applicable for the analysis of assessment items and is based on current education system. The divisions of questions into low order thinking skills, middle order thinking skills and high order thinking skills questions are used (Prashant Thote and L. Mathew, 2009).

In the present research it was assumed that lower order process categories are included into middle order and higher order. Questions which come under class of 'Analysis' also require cognitive processes like remember, apply and understand. Revised Bloom's Taxonomy does not include cumulative hierarchy like original Bloom's Taxonomy. Example- question most challenging require 'understanding' are cognitively more demanding as compared to easiest application task. It is now justified to apply the aforementioned definition because the central point of categories of cognitive process forms hierarchy.

\section{Data}

Data of research consist of 384 questions of grade 11 from 12 senior secondary schools of central India in the academic year 2018-19. Only question paper of chemistry considered for study. The questions are categorizes into highest possible of cognitive process. The questions required to explain demonstration categorized into cognitive based on low order thinking skills and based on recall, remembering. The questions not familiar to students categories into the create type. It is assumed in present research that low order thinking skills are included in higher categories also. Questions required conceptual and factual knowledge. The procedural knowledge-based questions require knowledge of methods. Example separation of Keratin by Kjeldahl method, factual knowledge required, knowledge of chemical formula eg., formula of Butane, and conceptual knowledge required knowledge of chemical basis.

\section{Phases of Research}

There are two phases of research

First Phase: The first phase of the present research is grade 11 chemistry question paper of term end examination of private senior secondary schools is classified into six cognitive processes (Categories of Bloom's Taxonomy Table-1). The six cognitive processes of Bloom's is further classified into three category as

1) Lower order thinking

2) Middle order thinking

3) High order thinking

Second Phase: The term end questions are classified into four knowledge categories of Blooms taxonomy (Table -2). The classification of chemistry questions with Bloom's taxonomy were interpretative partially and challenging also. The definition of high order thinking skills and low order thinking skills is concurrently applied to facilitate the process of classification. The 
fabricated frame work is useful while analysis of questions which lie at trough of Apply and Analysis categories of Blooms Taxonomy (Table-3).

In the present research the questions that require students to apply higher order cognitive skills in addition to used routine algorithms is analysed. Memorizing questions are classified into Analysed, Evaluate and Create as high thinking process categories. In lower thinking process categories questions classified require recall of information. It includes Apply, Understanding and Remember. Low order thinking skills require answers without understanding of solving process. Students perform better in examination with deep understanding of concepts and how solution has reached.

\section{Reliability}

Total ten percent of questions were picked up randomly and analysed by expert in chemical education and who has sound understanding of Bloom's Taxonomy and it is considered as a tool for classification. The kappa value was calculated for classification in knowledge dimension and cognitive process. The Cohen's Kappa value of cognitive process classification is (0.802) and knowledge classification is (0.986). The high Kappa value $(\mathrm{k}>0.75)$ for classification shows an excellent inter-rater agreement between raters and hence high reliability.

\section{Result}

Table 4:

\begin{tabular}{|l|c|c|c|c|c|c|}
\hline $\begin{array}{l}\text { Highest } \\
\text { knowledge }\end{array}$ & \multicolumn{2}{c|}{$\begin{array}{c}\text { Questions required } \\
\text { Low Order Thinking } \\
\text { Skills }\end{array}$} & $\begin{array}{c}\text { Questions required } \\
\text { Middle Order } \\
\text { Thinking Skills }\end{array}$ & $\begin{array}{c}\text { Questions required } \\
\text { High Order Thinking } \\
\text { Skills }\end{array}$ \\
\hline & \multicolumn{2}{|c|}{$54(14 \%)$} & \multicolumn{2}{c|}{$157(41 \%)$} & \multicolumn{2}{c|}{$173(45 \%)$} \\
\hline & Remember & Understanding & Apply & Analyse & Evaluate & Create \\
\hline Factual & & & & & & $26(7 \%)$ \\
\hline Conceptual & & $54(14 \%)$ & & $8(2 \%)$ & & \\
\hline Procedural & & & $34(9 \%)$ & $115(30 \%)$ & $61(16 \%)$ & $86(22 \%)$ \\
\hline $\begin{array}{l}\text { Meta- } \\
\text { Cognitive }\end{array}$ & & & & & & \\
\hline
\end{tabular}

Total 34\% questions require procedural knowledge analysis questions based on typical qualitative problems. Questions pertaining to chemical kinetics require graphical representation. Easy type questions on chemical phenomena and concepts. There are $22 \%$ of questions which require creative and procedural knowledge. The long answer type questions were also present. Some very long answers require interpretation. These are typically included finding limiting reagent and making approximation in the quantitative problems. Questions based on drawings of all possible structural isomers of organic compounds, questions based on evaluation of laboratory methods.

Total 14\% (54) questions are based on conceptual knowledge. There are questions in which students require to explain phenomena and concepts. The questions required to apply procedural knowledge were 9\% (34). The questions pertaining in which students have to write structural formula and perform routine calculations. There are questions based on periodic table and 
pertaining to real life application is also there. Total 7\% (26) questions require creative and conceptual knowledge.

\section{Conclusion}

Result of the present study indicates the grade 11chemistry term end examinations are cognitive in demanding. High order cognitive knowledge and skills questions are more as compared to literature and comparably with grade 12 question paper. Most of the questions in term end examinations are lower thinking skills and middle thinking skills.

End examination question paper requires higher order thinking skills. Many questions require analysis of procedural knowledge. Creation of conceptual knowledge-based questions is very few. Hence due attention is not given to high order thinking skills questions in chemistry questions of private school in the academic year 2018-19. Not a single question that require meta-cognitive is found in the study. It may be due to its very challenging and complex nature to assess Metacognitive level by using summative assessment instrument.

Question in chemistry at grade 11 year end examination must be significantly challenging. Revised Bloom's Taxonomy of cognitive objective is very useful in analysis of summative assessment. Result of the study reveals that grade 11 questions in chemistry are very suited for the assessment of high order thinking skills and knowledge skills.

Low order thinking skills type questions in chemistry can be utilized in designing process of future high order thinking skills type questions. They do enhance complexity of cognitive of routine quantitative problems is to add a short verbal section into questions that require students to have solving process sense and meaningful. It may be included with unknown ancillary material such as pictures, tables, charts, articles in questions of high order thinking skills than routine memorization of content of text book.

The cognitive complexity may increase by not presenting all necessary information eg. Acid based ionization content or solubility in examination questions specially when students need to first analyse the situation and then require to find all required information in ancillary the table of doing.

Result of the study is in line with (Kratwohol, 2002), zoller (1991), Rowe (1974) Tobin (1986).

\section{References}

[1] Prashant Thote Study of Blooms Taxonomy Levels Assigned to Examination at Senior Secondary Level, Journal of Research Extension and Development, 2249-8125.

[2] Prashant Thote, An Analysis of Chemistry Question Paper at Senior secondary Level: A Case Study, Journal of Research Extension and Development, 2319-1899.

[3] Prashant Thote, Assessment of Critical thinking in Chemistry in class XII students at private Secondary School in Central India, Journal of Research Extension and Development, 2319-1899.

[4] Prashant Thote, Application of Qualitative Reasoning in Chemistry at Senior Secondary School Level: An Educational Innovation, Journal of Research Extension and Development, 2319-1899. 
[5] Prashant Thote, Impact of Higher Order thinking Skills Questions on Chemistry Students performance, Journal of Research Extension and Development, 2319-1899, Vol. 001, No- 02, Pg 30-32.

[6] Prashant Thote, Conceptual understanding among senior secondary school students,

[7] International Journal Research Development, Vol 02, no-01, Pg 45-50.

*Corresponding author.

E-mail address: prashant.thote@rediffmail.com 